\title{
1. Introduction: achieving an optimal social policy mix
}

\section{Paul de Beer and Trudie Schils}

\section{A PARADIGM SHIFT IN SOCIAL POLICY: FROM PASSIVE TO ACTIVE MEASURES}

Since the 1990s it has become more or less conventional wisdom in most European countries that the predominant passive character of social policy should be replaced by more active measures. The welfare state that was built up in the post-Second World War period in Western Europe might have been quite successful in reducing poverty and providing income protection, but it proved unable to cope with the sharp rise of unemployment and the rapidly increasing numbers of benefit claimants after the oil shocks of the 1970s. Moreover, in the 1990s it became widely accepted that the rising number of beneficiaries was at least partly caused - or aggravated - by the passive character of the welfare state. From a failing solution to the problem of a malfunctioning economy, the welfare state became the problem itself.

During the 1990s, two main approaches were advocated to tackle the problems of the welfare state. The first was the (neo)liberal approach of welfare state retrenchment. To put it bluntly, this approach tries to remedy the flaws of the welfare state by reducing it and creating more room for the market and the private provision of income insurance. The main weakness of this approach is, of course, that it neglects the reasons why the welfare state was introduced in the first place, that is, to compensate for market failures. Shifting the responsibility for social protection from the state back to the market can give rise again to the unfavourable social consequences of market failures, such as high poverty levels, large income disparities and social exclusion of weaker groups. The second approach boils down to activating the welfare state. This approach was inspired by the alleged success of the Nordic welfare states, which for a long time were able to combine a high standard of social protection, low unemployment rates and high labour participation rates. The success of these welfare states is often attributed to their active labour market policies, which stimulate and 
support the unemployed to get back to work and facilitate the integration of all citizens in the labour market. During the 1990s, however, Sweden, the Scandinavian welfare state par excellence, experienced a deep economic crisis and record levels of unemployment, which forced the Swedish government to reform its welfare state, cut back expenses and reduce the generosity of social benefits. Although the Swedish economy has recovered, it is still questioned whether its welfare state will be sustainable in the end (Lindbeck 1997).

If the liberal approach guarantees the economic sustainability of the welfare state at the risk of increasing poverty and income insecurity, and the Nordic approach safeguards social protection without being sustainable in the long run, the obvious way out seems to combine the two approaches. This could be achieved by creating more room for a well-functioning self-regulating labour market on the one hand, while maintaining social protection and introducing activation measures on the other. Recently, a labour market policy concept has been developed that intends to achieve this. This so-called flexicurity approach is now an official goal of the European Union (EU), calling on the member states to 'promote flexibility combined with employment security' (EC 2005, p. 5) and 'convergence of views on the balance between flexibility and employment security, or flexicurity' (EC 2006, pp. 75-6). In 2007, the European Commission proposed a set of 'common principles of flexicurity' (EC 2007).

The flexicurity concept is not fully developed yet, nor is there a universally accepted definition. An important characteristic of the concept is that it refers to particular goals, namely flexibility and security, and not to particular instruments or measures. This probably explains its present popularity, since it fits nicely with the strategy of the open method of coordination (OMC), currently the common method for social policy in the EU. The OMC is tantamount to stating goals only, by means of so-called guidelines, and leaving it up to the EU member states to devise the measures to implement these goals. This allows each member state to choose the policy mix that fits its specific problems and circumstances best.

As pointed out by Wilthagen et al. (2003) the terms 'flexibility' and 'security' have various meanings. They distinguish four elements of flexibility and four kinds of security, and theoretically there can be 16 different combinations of flexibility and security. This makes the concept very broad and not very manageable for practical purposes. From the perspective of the welfare state debate, however, the most important elements of security seem to be income and employment security, ${ }^{1}$ and the most important element of flexibility the movement of individuals between jobs and between employment and non-employment (including unemployment 
and positions outside the labour market). ${ }^{2}$ This is also the position taken by the European Commission, which states: 'Flexicurity can be defined, more precisely, as a policy strategy to enhance, at the same time and in a deliberate way, the flexibility of labour markets, work organizations and labour relations on the one hand, and security - employment security and income security - on the other' (EC 2007).

Still, numerous policies affect these two kinds of security and this particular kind of flexibility. The literature, however, focuses on three categories of policies which specifically aim at a particular element of flexicurity. First of all, social security, and in particular unemployment benefits, is an important means for safeguarding income security by providing a social benefit to those who lose their job and/or are involuntarily out of work. Second, active labour market policies aim at promoting employment security, by enhancing the chances of finding a (new) job for those who lose their job or who enter the labour market. Third, labour market regulation generally reduces the flexibility of the labour market by restricting the unfettered working of the market. Deregulation, such as relaxing employment protection legislation, might be a means to enhance labour market flexibility and increase the flows between employment and non-employment.

In the next three sections, we successively discuss these three policy instruments to enhance flexicurity, and show that none of these on its own is sufficient to realize the intended combination of flexibility and security. Consequently, we discuss whether a combination of these measures yields better results and whether this might be called a 'golden triangle' of social policy.

\section{THE CORE OF SOCIAL PROTECTION: UNEMPLOYMENT BENEFITS}

At the core of each welfare state is a system of social security that provides income replacement for those who are involuntarily out of work and cannot, or are not required to, fall back on another source of income (such as capital income or income support from family members). All welfare states include a system of unemployment insurance, which provides either an earnings-related or a flat-rate cash benefit to employees who are (involuntarily) dismissed. There is a massive literature on the impact of these unemployment benefits on both income security and labour market flexibility. The general conclusion is that unemployment benefits enhance income security at the cost of reducing the outflow from unemployment to employment. 
To be more precise, there is ample empirical evidence that unemployment benefits reduce income disparities by transferring income from employed to unemployed workers (see Korpi and Palme 1998). It should be noted, however, that most empirical studies look at the direct impact of social benefits on income disparities by comparing the inequality of pre-tax and pre-transfer market incomes with the inequality of post-tax and post-transfer incomes. In other words, they compare the existing income disparities with the counterfactual in which there would be no social benefits, but everything else would be the same. This assumption is, of course, highly implausible, since most people would change their behaviour if they were no longer protected against the income loss caused by unemployment. One way to analyse these behavioural responses is by building a complex micro-econometric model, which includes individual choices between work and leisure time and the budget restriction that individuals face, due to the social security and tax system. However, these models are very sensible to the underlying assumptions and the estimated labour supply elasticities, which casts substantial doubt on the reliability of the outcomes of such models. An alternative method to study behavioural responses to variations in the social security system is by comparing different countries. Such cross-country comparisons are, however, hampered by the fact that countries differ in many respects, which makes it difficult to attribute income disparities to one particular element. Nevertheless, there is convincing empirical evidence that a more generous social security system reduces income inequality, even if one takes the behavioural responses of the population into account (Moller et al. 2003).

There are also numerous studies on the impact of unemployment benefits on the flexibility of the labour market, in particular the outflow from unemployment to work (some recent studies are Røed and Zhang 2003; Jenkins and García-Serrano 2004; Lalive and Zweimüller 2004; PollmannSchult and Büchel 2005). In a neoclassical economic framework it is selfevident that unemployment benefits cause a rise of the unemployment level, since the benefit itself reduces the costs of unemployment for the individual. Benefit recipients will search less intensively or raise their reservation wage (the lowest wage at which they are prepared to accept a job), which will prolong their unemployment duration, elevating the unemployment level. However, this simple economic model may not be very relevant in practice, since in the real world eligibility to unemployment benefits is subject to specific qualifying conditions, including the obligation to apply for jobs and to accept a job offer (Atkinson and Micklewright 1991).

Most of the empirical studies use micro-level data to analyse the impact of unemployment benefits on the behaviour of individual 
unemployed persons. These studies usually find relatively small and sometimes negligible effects of the benefit level on unemployment duration or the outflow to work. However, they often find much larger effects of a change of the benefit level, for example due to expiration of entitlements (for an overview, see Holmlund 1998). Moreover, sanctions (such as benefit reductions when not searching intensively enough) reduce the duration of unemployment and increasing the monitoring intensity even increases the exit probability of the non-sanctioned unemployed (Lalive et al. 2005).

Macro-studies usually take the form of cross-country comparisons of unemployment rates whereby the level of unemployment, among other factors, is related to the social security system. This is mostly accomplished by taking the so-called replacement rate (the benefit level as a percentage of the average wage) and/or the maximum benefit duration as a measure of the generosity of unemployment benefits. These cross-country studies are subject to the same criticism as studies that attempt to estimate the impact on income inequality, since it is very difficult to disentangle the effect of unemployment benefits from other factors. Nevertheless, there is some evidence of a positive relationship between the benefit generosity and the unemployment rate and the share of long-term unemployed in particular (Layard et al. 1991; Nickell et al. 2005).

In sum, there is broad agreement that a system of unemployment benefits reduces income inequality by narrowing the income gap between the employed and the unemployed population. There is less convincing evidence that unemployment benefits enhance unemployment by prolonging unemployment duration and reducing the outflow from unemployment to work.

\section{THE NEW ELEMENT: ACTIVE LABOUR MARKET POLICIES}

One reason why international comparisons do not show a strong relationship between unemployment insurance generosity and unemployment rates is that, for a long time, the Scandinavian countries succeeded in combining a generous social security system with low unemployment levels and small numbers of long-term unemployed. This success is often attributed to the active labour market policies that are carried out in these countries in addition to the social security system (sometimes called passive labour market policies) (Calmfors et al. 2002). Various measures to help the unemployed back to work are assumed to mitigate or even fully offset the unfavourable effects of generous benefits on unemployment. 
These measures include job brokerage, counselling, training, job sharing, direct job creation and specific measures for youth or for the disabled. If participation in these programmes is a precondition for receiving a benefit, these measures might also compensate for the disincentives caused by generous unemployment benefits (Madsen 2006 calls this the motivation effect of active labour market policy).

Although it seems obvious that active labour market policies promote the reintegration of the unemployed in the workforce, the majority of evaluation studies of specific programmes show only weak and often negligible effects. Some programmes are even found to be counterproductive, due to a locking-in effect, which tends to prolong unemployment spells merely because the unemployed individual cannot search for work while participating in an intensive training programme. In their survey of evaluation studies Martin and Grubb (2001) show that only some measures for some particular groups are effective, especially for women re-entering the labour market. Kluve (2006) gives an overview of 95 micro-evaluation studies and concludes that 'services and sanctions' (including job search assistance, vocational guidance and counselling) and 'private sector incentive schemes' (such as wage subsidies) are the most effective activation programmes (although he does not estimate their average effectiveness).

As with unemployment benefits, one can also explore the macro-impact of active labour market policies by comparing countries that differ in their efforts with respect to their activation policies or by studying changes in such policies in one particular country over time. Once again, one needs to disentangle the effect of activation strategies from the effect of other factors. Moreover, expenditures on active labour market policies tend to change countercyclically, since spending usually increases as unemployment rises. There is thus a bi-causal relationship between spending on activation and unemployment, which makes it even harder to estimate the impact of active labour market policies on unemployment. The few estimates of the macro-impact of active labour market policies that are available suggest that they only have a small or even negligible impact on the unemployment rate, and an even smaller impact on the employment rate (for an overview, see Kluve 2005, pp. 181-4).

In sum, although there is broad agreement among policy makers and politicians these days on the desirability of shifting the balance of social expenditure from passive to active labour market policies, the available empirical evidence hardly suggests that this is a promising way to counteract the unintended negative consequences of a generous unemployment insurance system. 


\section{THE MISSING LINK: EMPLOYMENT PROTECTION LEGISLATION}

Both unemployment benefits and active labour market policies aim at softening the unfavourable consequences of unemployment, either by providing income maintenance or by shortening unemployment spells. However, neither kind of policies directly affects the functioning of the labour market by reducing the risk of dismissal or increasing the number of people that are hired. This might be one explanation for the small effects of active labour market policy found in empirical research. Even if activation policies increase the probability of unemployed individuals getting back to work, it does not affect the total number of job hires, and thus might have only a small impact on the aggregate unemployment rate (although there might be a positive indirect effect by shifting the unemployment-vacancies curve to the left).

The number of dismissals and job hires and, consequently, the flows between employment and non-employment are influenced by the regulation of the labour market. Various laws and regulations affect these flows, including working time regulations and statutory minimum wages, but arguably the most important is employment protection legislation. This legislation states the conditions under which an employer may dismiss an employee. In most countries, employment protection legislation distinguishes permanent or regular contracts from temporary or fixed-term contracts. Often, there are also different rules and procedures regarding individual dismissals and collective dismissals.

Economic theory predicts that employment protection for permanent contracts has two opposing effects. On the one hand, it raises the costs of firing an employee and increases job tenure, lowering the inflow into unemployment, especially during an economic downturn. On the other hand, employment protection makes it more costly to hire someone who one might have to dismiss in the future, and reduces the number of job hires. Consequently, the outflow out of unemployment decreases. Theoretically, it is unclear which effect is larger and, thus, whether employment protection increases or decreases the unemployment rate. Since employment protection legislation unambiguously reduces the flows between employment and unemployment in both directions, it results on average in longer job tenures and longer unemployment spells, hence raising the share of the long-term unemployed (Bentolila and Bertola 1990). If protection for permanent contracts is stricter than that for temporary contracts, as is usually the case, this is expected to raise the share of temporary employment in total employment.

These theoretical expectations of the impact of employment protection 
on (un)employment and (un)employment duration are largely confirmed by empirical studies (for an overview see the survey by Deelen et al. 2006). Unemployment protection legislation (EPL) does not significantly affect the aggregate employment rate and unemployment rate, but it does reduce the reallocation on the labour market and increases average job tenure and average unemployment duration. Consequently, relaxing employment protection legislation will not raise the employment rate or reduce the unemployment rate, but will only have an impact on the distribution of employment and unemployment over duration classes.

\section{IS THERE AN OPTIMAL COMBINATION OF UNEMPLOYMENT BENEFITS, ACTIVATION POLICIES AND EMPLOYMENT PROTECTION?}

Despite the broad consensus on the desirability of shifting the balance of social policies towards active measures, to date there is not much empirical evidence that supports the benefits of such a shift. On the one hand, a generous social security system and strict employment protection legislation do not seem to have a large impact on the overall employment or unemployment rate. On the other hand, both evaluation and macrostudies show only small or negligible positive effects of active labour market policies. One reason for these small estimated effects might be the existence of complementarities between the various measures. The impact of one instrument may very well depend on another instrument. While each policy separately might only have a negligible effect, a wellchosen combination of policies might be more effective than the sum of the separate policies. There can be various reasons for such complementarities (Blanchard and Tirole 2004; Eichhorst and Konle-Seidl 2005). If the unemployment benefit replacement rate is high and eligibility criteria are weak, the obligation to participate in an activation programme might compensate for the disincentives of the benefit, through the so-called motivation effect discussed before (Madsen 2006). If benefit levels are much lower and the incentives to leave unemployment much stronger, the motivation effect will not make much difference. Mandatory training programmes might thus be more effective, the higher the replacement rates are. A high replacement rate also makes it less costly for employers to dismiss workers, since employees will not resist dismissal fiercely if they only expect to suffer a small income loss. Hence, the employer can shift most of the (social) costs of unemployment on to society. This may result in excessive numbers of dismissals, which can be counterbalanced by strict employment regulation. If replacement rates are low, employment 
protection might lead to too few dismissals and thus hinder reallocation on the labour market. Furthermore, very strict employment protection might reduce the effectiveness of active labour market policies, since there are little job openings and even qualified job seekers might find it difficult to find a job.

If there are indeed complementarities between the various social policies, then there might be an optimal combination of unemployment insurance, active labour market policies and employment protection that renders the best results in terms of both flexibility and security. The European Commission states: 'A successful flexicurity strategy has to balance carefully the income insurance function of the unemployment benefit system with an appropriate activation strategy designed to facilitate transitions into employment and boost career development' (EC 2007, p. 7). Recently, it has been suggested that Denmark might be close to such an optimal combination of policies, for which reason some authors even refer to it as the 'golden triangle' (Bredgaard et al. 2005; EC 2007, p. 36). The three angles of the Danish policy triangle include generous unemployment benefits, high spending on active labour market policies and weak employment protection legislation. The first guarantees income maintenance in case of job loss, the second secures a quick return to the labour market for those who lose their job and the third stimulates a flexible labour market with large flows between employment and unemployment.

Although Denmark is one of the best-performing Organisation for Economic Co-operation and Development (OECD) countries with respect to the employment rate, the unemployment rate and the share of long-term unemployment, one can nevertheless question whether this good performance is really caused by this combination of policies. Does Danish social policy indeed constitute a golden triangle? To date, there are only a few studies that estimate the impact of the combination of various policies on labour market performance. Boone and van Ours (2004) analyse the joint impact of unemployment benefits and activation policies and conclude that the effect of training on the unemployment rate is larger the higher the replacement rate is. They do not find any complementarities between unemployment benefits and other elements of active labour market policies, such as, public employment services and subsidized jobs. However, they do not include employment protection legislation in their analysis. Belot and van Ours (2004) analyse the interaction effects of benefit generosity and tax rates, employment protection and centralization of bargaining, and union density and centralization of bargaining. They conclude that institutions matter and that they interact. The interaction between tax rates and benefit generosity, in particular, explains the reduction of unemployment rates in most European countries. However, they do not analyse the interaction 
effect of employment protection and unemployment benefits, and active labour market policy is left out of their study.

Kluve (2006) performs a meta-analysis of micro-evaluation studies of active labour market policies and finds that stricter employment protection reduces the likelihood that specific labour market programmes are effective, but he does not find a significant impact of unemployment benefit replacement rates. In a study of the OECD (2006) interactions are tested between benefit replacement rates and employment protection on the one hand and the overall institutional framework (measured by union density, collective bargaining coverage, the extent of corporatism and product market competition) on the other. The conclusion is that "no firm conclusions can be drawn regarding the presence of specific interactions between the policies and institutions included in the baseline specification' (OECD 2006, p. 214). Moreover, it is stated that 'policy complementarities are estimated to amplify the unemployment effects of separate reforms by only 12 to 19 per cent' (OECD 2006, p. 216). However, of the three policy areas discussed above, this part of the analysis only includes unemployment benefits. In another analyses the OECD finds 'that the adverse impact of unemployment benefits is lower in countries that spend more on ALMPs' (OECD 2006, p. 217).

In conclusion, the empirical evidence for complementarities between various elements of social policy is limited and rather weak. The few available studies do not seem to warrant the existence of a golden triangle, which renders an optimal combination of flexibility and security. However, none of these studies analyses the possible complementarities between unemployment benefits (UBs), active labour market policies (ALMPs) and employment protection legislation simultaneously. Therefore, in the next section we present the results of an explorative empirical analysis that does take all three elements of social policy into account at the same time.

\section{A STATISTICAL ANALYSIS OF THE JOINT IMPACT OF UB, ALMP AND EPL}

For the analysis, we use data for 25 OECD countries covering the period 1985-2004. Data are retrieved from the OECD Labour Force Surveys, the OECD Social Expenditure Database and the CEP-OECD Institutions dataset (see Nickell 2006). Our analysis differs in a number of aspects from that in OECD (2006) and Bassanini and Duval (2006). We include the three components of the policy triangle and their interaction terms simultaneously. Our main interest is in the long-term impact of policy instruments on structural unemployment and trends in labour market flows. Therefore 
we base our analysis on five-year averages, leaving us with four time periods: $1985-9,1990-4,1995-9$ and 2000-4. Consequently, we do not analyse the short-term impact of the various policies on the evolution of the unemployment rate over the business cycle, but the long-term impact on trends in average unemployment rates over consecutive business cycles. Although the use of period averages reduces the number of cases for our analysis, and thus makes it harder to find statistically significant effects, if we do find significant effects they are more likely to be robust. To faciliate interpretation of the estimated effects, we use deviations from the means in the relevant period. ${ }^{3}$

As dependent variables we include not only the overall unemployment and employment rates, but also the flows between employment and nonemployment. After all, we are especially interested in a mix of policies that increases both security and flexibility. Labour market flexibility is better measured by labour market flows than by the stocks of employed and unemployed at a particular point in time. As a proxy for these labour market flows we take the share of long-term unemployment (unemployed longer than one year), the inflow into unemployment and the inflow into employment. The inflow into unemployment is calculated as the number of persons who are unemployed for less than one month, multiplied by 12, expressed as a percentage of the population aged between 15 and 64. This indicator measures the probability of becoming unemployed within a year for the average member of the working-age population. As a proxy for the inflow into employment we take the number of persons who are employed for less than one year as a percentage of total employment.

In addition, we construct a new indicator to measure income (in)security or the expected income loss due to unemployment, reflecting the difference in the expected income when unemployed and the average wage. It is calculated as the probability of being unemployed multiplied by the average replacement income during an unemployment spell (which is calculated as total expenditure on unemployment benefits divided by the number of unemployed) as a percentage of the average wage. This expected relative replacement income is subtracted from 100 to get the expected relative income loss due to unemployment (refer to the Appendix to this chapter for the technical details). This gives us a proxy for the 'security' part of flexicurity in each country.

The independent variables included in the models reflect the three policy instruments discussed above: that is, employment protection, unemployment insurance and active labour market policy. For employment protection legislation we take the OECD Employment Protection Legislation Index (OECD 2004). To reflect unemployment insurance we use the average OECD overall gross replacement rates for the first five years of 
unemployment, summarized over four different family types and three different income levels. Finally, as a proxy for active labour market policies we use the expenditures on active labour market policy expressed as a percentage of gross domestic product (GDP). This is the only cross-country measure available. However, we acknowledge the problems of bi-causality with active labour market policy and labour market outcomes such as the unemployment rate. In part we try to minimize this problem by using five-year averages. In addition, we try to correct more formally for this by using a two-step analysis (see the Appendix to this chapter for details on this method). In a first regression we estimated the relation between activation policies and GDP growth to find the cyclical part of expenditure on active labour market policy. From this regression we take the country fixed effects, that represent the policy part of the expenditure on active labour market policy, and include these in the analysis for the effect of the policy instruments on labour market outcomes. In doing so, we hope to reduce the problem of bi-causality to a minimum.

Apart from estimating the direct effects of the three policy variables on the labour market outcomes, we include the interactions between each pair of policy variables, as well as the interaction between the three policy variables. If a golden triangle really exists, we expect this last interaction term in particular to be significant, since that would imply that the full composition of the policy triangle matters. Detailed information on the analyses (such as the methods used, descriptive statistics of the included variables and the exact regression results) can be found in the Appendix to this chapter; Table 1.1 summarizes the estimation results.

The results of this explorative analysis are illustrative. Our analysis shows hardly any direct effects of the policy instruments, only expenditure on activation is positively related to the unemployment rate, the share of long-term unemployment and the expected income loss due to unemployment. The positive relation with the unemployment rate has been found before in the literature, when using this measure for active labour market policy and might still be caused by the bi-causal relation between the two variables (Calmfors et al. 2002). However, it might also be evidence of the earlier-mentioned locking-in effect of activation policies.

Although there are few direct effects, the results show a number of interesting bilateral interaction effects of the policy variables. First, the interaction between employment protection and unemployment benefits is significant in four models. When employment protection is stricter, more generous unemployment benefits result in a lower employment rate, a higher unemployment rate, a larger share of long-term unemployment and a larger expected income loss due to unemployment. This was expected from theory, since more strict employment protection reduces the number 
Table 1.1 Summary of regression analysis of labour market policy on labour market outcomes

\begin{tabular}{lccc}
\hline & $\begin{array}{c}\text { Employment } \\
\text { rate }\end{array}$ & $\begin{array}{c}\text { Unemployment } \\
\text { rate }\end{array}$ & $\begin{array}{c}\text { Share of long-term } \\
\text { unemployment }\end{array}$ \\
\hline EPL & 0 & 0 & 0 \\
UB & 0 & 0 & 0 \\
ALMP & 0 & + & + \\
EPL*UB & - & + & + \\
EPL*ALMP & + & - & - \\
UB*ALMP & 0 & 0 & 0 \\
EPL*UB*ALMP & 0 & 0 & + \\
\hline & Inflow into & Inflow into & Expected income \\
& unemployment & employment & loss due to \\
& & & unemployment \\
\hline EPL & - & 0 & 0 \\
UB & 0 & 0 & 0 \\
ALMP & 0 & 0 & + \\
EPL*UB & 0 & 0 & + \\
EPL*ALMP & 0 & 0 & 0 \\
UB*ALMP & 0 & 0 & 0 \\
EPL*UB*ALMP & 0 & 0 & + \\
\hline
\end{tabular}

Note: For full regression results, see the Appendix of Chapter 1.

Source: Authors' own calculations.

of job hires and the mobility on the labour market, reducing the exit probability out of unemployment. This latter effect is aggravated by more generous unemployment benefits, that minimize the negative income effects of unemployment, raising the reservation wage. Apparently, the effect of the higher unemployment risk on the expected income loss is larger than the effect of a higher replacement rate.

Second, the interaction between employment protection and active labour market policy has a significant impact on four of the dependent variables, basically showing the reverse effects of the interaction between employment protection and unemployment benefits. As the employment protection becomes stricter, spending more on activation policies results in higher employment, lower unemployment, less long-term unemployment and a smaller expected income loss due to unemployment. It seems plausible that the higher activation expenditure offsets the unfavourable impact of strict employment protection (or the reduced flexibility of the 
labour market). The theoretical expectation of a diminished effectiveness of active labour market policies when employment protection is stricter is not supported by our analysis. Thus, it appears that large expenditure on active labour market policy has some unfavourable effects if employment protection is average, but has a positive impact if it is strict.

Third, there is no significant interaction effect of unemployment benefits and active labour market policy. This is somewhat surprising since it is generally believed that stronger activation policies can offset the negative effects of benefit generosity on unemployment duration. Finally, the estimation results show hardly any overall interaction effect between the three policy instruments, apart from a weakly significant effect on the share of long-term unemployment. More strict employment protection combined with higher unemployment benefit generosity and higher expenditure on active labour market policy is associated with a larger share of long-term unemployed. Interestingly, this occurs in addition to and in the opposite direction of the above-mentioned bilateral interaction between employment protection and expenditure on activation policies. This means that although spending more on activation is more effective if employment protection is stricter, this favourable effect is weaker the more generous unemployment benefits are.

In short, the estimation results show that only employment protection and active labour market policy have a direct effect on some of the labour market outcomes, both in an unfavourable direction. The observed bilateral interaction effects between the labour market institutions in our analysis on the labour market outcomes suggest that complementarities between the policy instruments exist and should be accounted for in labour market analyses. Moreover, our statistical search for the golden triangle seems to be bogged down. We found only minor interactions between all three angles of the policy triangle. This raises the question whether a golden triangle of social policy that renders an optimal combination of security (low unemployment rate and high income security) and flexibility (large flows between employment and unemployment) exists. However, this should not be interpreted to imply that the social policy mix is irrelevant, since the combination of measures explains roughly between one-third and half of the variance of the dependent variables in our regression analyses.

\section{IMPLEMENTATION AND ADMINISTRATION}

There might be various causes for the weak statistical evidence for consistent policy complementarities between the three policies. Before lapsing 
into the conclusion that the social policy mix has no role at all to play in improving labour market performance and income security, we prefer to examine another possible cause, which is that the indicators used in the statistical analysis are too general and too crude to serve as measures of the subtleties of social policy in practice. Measuring active labour market policy by aggregate public expenditure as a percentage of GDP simply misses the large variety in activation strategies in different countries. For example, spending 0.3 per cent of GDP on subsidized jobs may have a completely different effect than spending the same amount on job brokerage or training (Calmfors et al. 2002; Kluve 2006). Likewise, the OECD employment protection indicator summarizes a wide range of components of labour law into one figure. This has led to some criticism, mainly because of the rather crude and subjective coding frame (Bertola et al. 2000). In addition, the indicator only takes account of national legislation, while in some countries employment protection is further regulated in collective agreements (Schils, 2007). Two countries scoring equally on the OECD indicator may very well have strongly diverging systems of employment protection. Finally, the overall OECD indicator for the replacement rate is a summary measure of the replacement rate in a number of different situations, but does not include entitlement conditions. Although it would be possible to disaggregate these general indicators into their constituent parts, the number of indicators that are available for a statistical analysis would soon exceed the number of observations, making a statistical analysis impossible. ${ }^{4}$ To get a better insight into the impact of these specific elements of the policy triangle one has to resort to a qualitative, in-depth analysis of social policy in a number of countries.

A further reason why the indicators used may not be adequate for determining the impact of social policy, is that they only measure the 'intensity' of social policy, in terms of income replacement (UB), spending (ALMP) and rights (EPL), but they do not take into account the way these policies are put into practice. The indicators give no information about the actors that are responsible for implementing and administering these policies.

Which actors are involved in social policy? Most studies and debates since the 1980s have focused on the roles of the state and the market, strongly suggesting that there is a dichotomy with respect to the distribution of responsibility. However, as early as 1985, Streeck and Schmitter (1985) pointed out that there is a third kind of actor involved, namely intermediate organizations or associations, including trade unions and employers' associations. ${ }^{5}$ In many countries these so-called social partners have played and still play an important role in social policy. In some countries they merely have an advisory role to the government on social policy, whereas in other countries the trade unions are involved in the 
actual administration of unemployment insurance (Belgium, Denmark, Sweden). The social partners may play a role in implementing active labour market policies as well, and collective agreements between trade unions and employers (or their associations) may include additional provisions with respect to unemployment benefits, employment protection and training measures. However, these extensions of the legal provisions are not included in the indicators used for our statistical analysis.

It is likely that the particular role of the various actors matters quite a lot for the effectiveness of social policy. For example, if the actor that pays out unemployment benefits is also responsible for implementing active labour market policy, it is more likely that these policies are coordinated and attuned than if different actors are responsible for them. After all, it is more profitable to increase the budget for active labour market policy if one can claw back part of the extra spending by reducing the number of persons who claim unemployment benefits. Likewise, if statutory unemployment benefits are paid out by a public body while a top-up is administered by the social partners, this might harm the coherence of unemployment insurance policy. Moreover, it is likely that a principalagent problem arises when different actors are responsible for the legislation and the implementation of social policy, since the legislator (the government) and the administrator (an independent body) may not have the same objectives.

The importance of the role of the social partners with respect to policies to promote flexicurity is acknowledged by the European Commission, as it states: 'active involvement of social partners is key to ensure that flexicurity delivers benefits at all', and: 'Social partners are best placed to address the needs of employers and workers and detect synergies between them' (EC 2007, p. 8). This makes it essential to take account of the role of the social partners in assessing the impact of social policy. However, hardly any study in this field has paid explicit attention to their role. Therefore, this will be an important contribution of the in-depth country studies in this book.

\section{FROM QUANTITATIVE TO QUALITATIVE ANALYSIS: THE PURPOSE OF THIS BOOK}

For the reasons spelled out in the preceding section a purely quantitative, statistical analysis will not do in finding out the best combination of unemployment benefits, employment protection and active labour market policy to enhance flexicurity. We have to investigate the peculiarities and idiosyncrasies of social policy in separate countries to determine which 
characteristics are essential in explaining the successes and failures of these countries with respect to social protection and labour market performance. To accomplish this we have to perform a qualitative, in-depth study of the social policy triangle in each country separately. Therefore, the main part of this book consists of a number of case studies of social policies to tackle the unemployment risk in a selection of European countries. The selection of these countries is based on two principles. First, we include countries that are somewhat similar with respect to their socio-economic context, so that it is likely that differences between these countries regarding (income) security and labour market performance are for a considerable part due to differences in their social policy. Second, we need sufficient variation in the kind of social policies and the role of various actors (government, social partners, private companies) to be able to attribute differences in performance to these factors. These criteria resulted in the selection of Belgium, Denmark, France, Germany, the Netherlands, Sweden and the United Kingdom.

The next seven chapters give an extensive overview and discussion of the social policy triangle in these countries. Each chapter discusses the main changes in each of the three policy areas since the 1990s and then describes the main characteristics of the present policy, including the administration and the distribution of responsibility between the various actors involved. The last part of each chapter discusses the interaction between the three components of the social policy triangle and tries to assess its effectiveness with respect to flexicurity. In the final chapter we compare the design of social policy in the seven countries, establish the main differences and similarities and find out whether the social policy mix in the various countries is converging or diverging. Finally, we draw some conclusions from the lessons learned in the country chapters and try to answer the question whether there exists something like a 'golden triangle' after all.

\section{NOTES}

1. Wilthagen et al. (2003) distinguish employment security from job security, which refers to the security of keeping one's present job, but one could also consider job security to be a specific element of employment security. Their fourth element of security is combination security, which refers to the combination of paid work and other, unpaid activities, such as child care. This kind of security will not be discussed in this book.

2. This roughly coincides with what Wilthagen et al. (2003) call 'numerical-external flexibility'. However, this term seems to refer primarily to the need of flexibility of the employer and does not include the outflow out of unemployment or inactivity into work. The other elements that Wilthagen et al. distinguish are numerical-internal flexibility (such as overtime and part-time work), functional flexibility (such as multitasking, job rotation) and wage flexibility, which we will leave aside. 
3. Details on the variables and methods used are presented in the Appendix to this chapter.

4. In some empirical studies (Nickell et al. 2005) more explanatory variables are included by using a pooled time-series cross-section analysis in which each year for each country is an observation, which increases the total number of observations strongly. However, such a regression analysis mainly explains the short-term cyclical variation in the dependent variable and does not give much insight into structural shifts in the long run.

5. Streeck and Schmitter (1985) include community as a fourth actor, but this actor will be left aside in our study.

\section{REFERENCES}

Atkinson, A.B. and J. Micklewright (1991), 'Unemployment compensation and labour market transitions: a critical review', Journal of Economic Literature, 29(4): 1679-1727.

Bassanini, A. and R. Duval (2006), 'Employment patterns in OECD countries: reassessing the role of policies and institutions', OECD social, employment and migration working papers no. 35, Paris.

Belot, M. and J.C. van Ours (2004), 'Does the recent success of some OECD countries in lowering their unemployment rates lie in the clever design of their labour market reforms?' Oxford Economic Papers, 56: 621-42.

Bentolila, S. and G. Bertola (1990), 'Firing costs and labour demand: how bad is Eurosclerosis?' Review of Economic Studies, 57(3): 381-402.

Bertola, G., T. Boeri and S. Cazes (2000), 'Employment protection in industrialized countries: the case for new indicators', International Labour Review, 139: $57-72$.

Blanchard, O. and J. Tirole (2004), 'The optimal design of unemployment insurance and employment protection: a first pass', mimeo.

Boone, J. and J.C. van Ours (2004), 'Effective active labour market policies', IZA discussion paper no. 1335, Bonn.

Bredgaard, T., F. Larsen and P.K. Madsen (2005), 'The flexible Danish labour market: a review', Aalborg University/CARMA research paper 01:2005, Aalborg.

Calmfors, L., A. Forslund and M. Hemström (2002), 'Does active labour market policy work? Lessons from Swedish experiences', Institute for Labour Market Policy Evaluation working paper no. 2002-4, Uppsala.

Deelen, A., E. Jongen and S. Visser (2006), 'Employment protection legislation. Lessons from theoretical and empirical studies for the Dutch case', CPB Netherlands Bureau for Economic Policy Analysis document no. 135, The Hague.

EC (European Commission) (2005), Integrated Guidelines for Growth and Jobs (2005-2008), communication to the Spring European Council, Brussels: EC.

EC (2006), Employment in Europe 2006, report of the Directorate-General for Employment, Social Affairs and Equal Opportunities, Brussels: EC.

EC (2007), Towards Common Principles of Flexicurity: More and Better Jobs through Flexibility and Security, report of the Directorate-General for Employment, Social Affairs and Equal Opportunities, Brussels: EC.

Eichhorst, W. and R. Konle-Seidl (2005), 'The interaction of labour market 
regulation and labour market policies in welfare state reform', Institute for Labour Studies (IZA) discussion paper no. 1718, Bonn.

Holmlund, B. (1998), 'Unemployment insurance in theory and practice', Scandinavian Journal of Economics, 100: 113-41.

Jenkins, S.P. and C. García-Serrano (2004), 'The relationship between unemployment benefits and re-employment probabilities: evidence from Spain', Oxford Bulletin of Economics And Statistics, 66(2): 239-60.

Kluve, J. (ed.) (2005), Study on the Effectiveness of ALMPs, report for the European Commission, Essen: Rheinsch-Westfaliches Institut für Wirtshafsfatschung (RWI).

Kluve, J. (2006), 'The effectiveness of European active labour market policy', Institute of Labour Studies (IZA) discussion paper no. 2018, Bonn: IZA.

Korpi, W. and J. Palme (1998), 'The paradox of redistribution and strategies of equality: welfare state institutions, inequality, and poverty in the Western countries', American Sociological Review, 63(5): 661-87.

Lalive, R. and J. Zweimüller (2004), 'Benefit entitlement and unemployment duration: the role of policy endogeneity', Journal of Public Economics, 88: 2587-616.

Lalive, R., J. Zweimüller and J.C. van Ours (2005), 'The effect of benefit sanctions on the duration of unemployment', Journal of the European Economic Association, 3(6): 1386-417.

Layard, R., S. Nickell and R. Jackman (1991), Unemployment: Macroeconomic Performance and the Labour Market, Oxford: Oxford University Press.

Lindbeck, A. (1997), 'The Swedish experiment', Journal of Economic Literature, 35: $1273-319$.

Madsen, P.K. (2006), 'How can it possibly fly? The paradox of a dynamic labour market in a Scandinavian welfare state', in Johan A. Campbell, Johna A. Hall and Ove K. Pedersen (eds), National Identity and the Varieties of Capitalism: The Danish Experiment, Montreal: McGill Queen's University Press, pp. 321-55.

Martin, J.P. and D. Grubb (2001), 'What works and for whom: a review of OECD countries' experiences with active labour market policies', Swedish Economic Policy Review, 8: 9-56.

Moller, S., E. Huber, J.D. Stephens, D. Bradley and F. Nielsen (2003), 'Determinants of relative poverty in advanced capitalist democracies', American Sociological Review, 68(1):22-51.

Nickell, S. (2006), 'The CEP-OECD institutions data set 1960-2004', Centre for Economic Performance discussion paper no. 759, London.

Nickell, S., L. Nunziata and W. Ochel (2005), 'Unemployment in the OECD since the 1960s: what do we know?' Economic Journal, 115: 1-27.

OECD (2004), 'Employment protection regulation and labour market performance', in OECD Employment Outlook 2004, Paris: OECD, pp. 61-125.

OECD (2006), 'Reassessing the role of policies and institutions for labour market performance: a quantitative analysis', in OECD Employment Outlook 2006, Paris: OECD, pp. 207-31.

Pollmann-Schult, M. and F. Büchel (2005), 'Unemployment benefits, unemployment duration and subsequent job quality: evidence from West Germany', Acta Sociologica, 48(1): 21-39.

Røed, K. and T. Zhang (2003), 'Does unemployment compensation affect unemployment duration?', Economic Journal, 113: 190-206.

Schils, T. (2007), 'Employment protection in Dutch collective agreements', 
Amsterdam Institute for Advanced Labour Studies working paper no. 56, Amsterdam.

Streeck, W. and P.C. Schmitter (1985), 'Community, market, state - and associations? The prospective contribution of interest governance to social order', European Sociological Review, 1(2): 119-38.

Wilthagen, T. (1998), 'Flexicurity: a new paradigm for labour market policy reform?,' Wissenschaftszentrum discussion paper no. 202, Berlin.

Wilthagen, T., F. Tros and H. van Lieshout (2003), 'Towards "flexicurity"? Balancing flexibility and security in EU member states', paper for the 13th World Congress of the International Industrial Relations Association, Berlin, September. 


\section{APPENDIX: REGRESSION DETAILS}

Countries included in the analysis are Australia (AUS), Austria (AUT), Belgium (BEL), Canada (CAN), the Czech Republic (CZE), Denmark (DNK), Finland (FIN), France (FRA), Germany (DEU), Greece (GRC), Hungary (HUN), Ireland (IRE), Italy (ITA), Luxembourg (LUX), the Netherlands (NLD), New Zealand (NZL), Norway (NOR), Poland (POL), Portugal (PRT), Slovak Republic (SLK), Spain (ESP), Sweden (SWE), Switzerland (CHE), the United Kingdom (UK) and the United States (USA). Table 1A.1 shows data availability for these countries.

To estimate the effect of the policy instruments of interest on several labour market outcomes, the following three linear regression models are used:

1. Basic model

$$
Y_{j t}=\alpha_{j}+\alpha_{t}+\beta_{1} X_{1 j t}+\beta_{2} X_{2 j t}+\beta_{3} X_{3 j t}+\eta_{j t}
$$

2. Model with bilateral interactions

$$
\begin{aligned}
Y_{j t}= & \alpha_{j}+\alpha_{t}+\beta_{1} X_{1 j t}+\beta_{2} X_{2 j t}+\beta_{3} X_{3 j t}+\beta_{4} X_{1 j t} X_{2 j t}+\beta_{5} X_{1 j t} X_{3 j t} \\
& +\beta_{6} X_{2 j t} X_{3 j t}+\eta_{j t}
\end{aligned}
$$

3. Model with trilateral interactions

$$
\begin{aligned}
Y_{j t}= & \alpha_{j}+\alpha_{t}+\beta_{1} X_{1 j t}+\beta_{2} X_{2 j t}+\beta_{3} X_{3 j t}+\beta_{4} X_{1 j t} X_{2 j t}+\beta_{5} X_{1 j t} X_{3 j t} \\
& +\beta_{6} X_{2 j t} X_{3 j t}+\beta_{7} X_{1 j t} X_{2 j t} X_{3 j t}+\eta_{j t}
\end{aligned}
$$

where $j=1, \ldots, 25$ is the number of the countries; $t=1, \ldots, 4$ is the number of the time periods, $\alpha_{j}$ are the country fixed-effects, $\alpha_{t}$ are the period fixedeffects, $Y_{j t}$ is a set of dependent variables, $X_{j t}$ is a set of independent variables and $\eta_{j t}$ is the error term. The set of dependent variables consists of the employment rate (employed population as a percentage of total population aged between 15 and 64), unemployment rate (number of unemployed as a percentage of the labour force), share of long-term unemployment (percentage of unemployed with unemployment spell longer than one year), inflow into unemployment (number of people with unemployment spell less than one month multiplied by 12 , as a percentage of the labour force), inflow into employment (number of people with employment spell shorter than one year as a percentage of total employed) and the expected income 
Table 1A.1 Data availability for regression analysis of the effectiveness of labour market policy

\begin{tabular}{cl}
\hline Employment rate & $\begin{array}{l}\text { Available for 1985-2004, except for HUN (1992-2004) } \\
\text { and SLK (1994-2004). }\end{array}$ \\
Unemployment & Available for 1985-2004, except for CZE (1990-2004), \\
rate & HUN (1992-2004), POL (1990-2004) and SLK \\
& (1994-2004). \\
Share of long-term & Available for 1985-2004, except for AUT (1994-2004), \\
unemployment & CHE (1991-2004), CZE (1993-2004), HUN (1992-2004), \\
& NZL (1986-2004), POL (1992-2004), POR (1986-2004) \\
and SLK (1994-2004). \\
Anflow into & Available for 1985-2004, except for AUT (1994-2004), \\
unemployment & NHE (1991-2004), CZE (1993-2004), HUN (1992-2004), \\
& NZL (1986-2004), POL (1992-2004), POR (1986-2004) \\
and SLK (1994-2004). \\
Available for 1993-2004, except for AUS (n.a.), AUT \\
(n.a.), CHE (1996-2004), CZE (1997-2004), FIN (1995- \\
2004), GRC (1992-2001), HUN (1997-2004), NZL (n.a.), \\
NOR (1995-2004), POL (1997-2004), SLK (n.a.), SWE \\
(1995-2004) and USA (n.a.). \\
Available for 1985-2004, except for AUT (1990-2004), \\
CZE (1993-2004), HUN (1995-2004), NZL (1986- \\
Expected income & 2004), POL (1991-2004), POR (1989-2004) and SLK \\
loss due to & (1995-2004). \\
unemployment & Available for 1985-2003, except for AUT (n.a.), CZE \\
(1993-2004), HUN (1990-2004), LUX (n.a.), NZL (1990- \\
EPL indicator
\end{tabular}

Sources: OECD (2004), Employment Outlook, OECD (2008), Labour Force Statistics, online database, Paris: OECD; OECD (2008), Social Expenditure Database, online database, Paris: OECD.

loss due to unemployment (the probability of being unemployed multiplied by the average replacement income during an unemployment spell - which is calculated as total expenditure on unemployment benefits divided by the number of unemployed - as a percentage of the average wage $\left.{ }^{1}\right)$.

The set of independent variables consists of the OECD employment protection indicator (measuring the strictness of EPL on 18 items, ranging 
Table 1A.2 Summary statistics for dependent and independent variables

\begin{tabular}{|c|c|c|c|c|c|}
\hline & & $1985-89$ & $1990-94$ & 1995-99 & $2000-2004$ \\
\hline \multirow{3}{*}{$\begin{array}{l}\text { Employment } \\
\text { rate }\end{array}$} & Mean & 65.9 & 65.6 & 65.8 & 68.2 \\
\hline & Min & 47.5 (ESP) & 49.0 (ESP) & 50.3 (ESP) & 53.2 (POL) \\
\hline & $\operatorname{Max}$ & 80.1 (USA) & 84.8 (CHE) & 83.2 (LUX) & 94.1 (LUX) \\
\hline \multirow{3}{*}{$\begin{array}{l}\text { Unemploy- } \\
\text { ment rate }\end{array}$} & Mean & 8.6 & 8.6 & 8.5 & 7.3 \\
\hline & Min & 0.7 (CHE) & 1.5 (LUX) & 2.4 (LUX) & 2.2 (LUX) \\
\hline & $\operatorname{Max}$ & 19.1 (ESP) & 19.3 (ESP) & 19.8 (ESP) & 18.5 (ESP) \\
\hline \multirow{3}{*}{$\begin{array}{l}\text { Share of } \\
\text { long-term } \\
\text { unemploy- } \\
\text { ment }\end{array}$} & Mean & 36.2 & 33.5 & 37.3 & 32.8 \\
\hline & Min & 7.3 (NOR) & 9.3 (USA) & 8.5 (USA) & 6.4 (NOR) \\
\hline & Max & 72.3 (BEL) & 62.7 (ITA) & 62.6 (ITA) & 57.9 (SLK) \\
\hline \multirow{3}{*}{$\begin{array}{l}\text { Inflow into } \\
\text { unemploy- } \\
\text { ment }\end{array}$} & Mean & 9.1 & 11.5 & 10.4 & 13.6 \\
\hline & Min & 1.0 (POR) & 2.8 (LUX) & 2.7 (NET) & 2.3 (NET) \\
\hline & $\operatorname{Max}$ & 32.6 (USA) & 35.6 (USA) & 22.9 (USA) & 22.6 (USA) \\
\hline \multirow{3}{*}{$\begin{array}{l}\text { Inflow into } \\
\text { employment }\end{array}$} & Mean & & 12.0 & 12.9 & 13.0 \\
\hline & Min & n.a. & 4.8 (ITA) & 6.2 (LUX) & 6.3 (LUX) \\
\hline & $\operatorname{Max}$ & & 21.2 (ESP) & 23.9 (DEN) & 20.6 (DEN) \\
\hline \multirow{3}{*}{$\begin{array}{l}\text { Expected } \\
\text { income loss } \\
\text { due to } \\
\text { unemploy- } \\
\text { ment }\end{array}$} & Mean & 5.3 & 5.9 & 6.4 & 5.5 \\
\hline & Min & 0.1 (LUX) & 0.6 (LUX) & 0.1 (DEN) & 0.1 (DEN) \\
\hline & Max & 16.5 (ESP) & 14.6 (ESP) & 16.6 (ESP) & 17.6 (POL) \\
\hline \multirow{3}{*}{$\begin{array}{l}\text { EPL } \\
\text { indicator }\end{array}$} & Mean & 2.4 & 2.2 & 2.0 & 1.9 \\
\hline & Min & 0.2 (USA) & 0.2 (USA) & 0.2 (USA) & 0.2 (USA) \\
\hline & $\operatorname{Max}$ & 4.2 (POR) & 3.9 (POR) & 3.7 (POR) & 3.6 (POR) \\
\hline \multirow[t]{3}{*}{ UB generosity } & Mean & 28.7 & 29.9 & 31.5 & 28.3 \\
\hline & Min & 1.1 (ITA) & 9.9 (ITA) & 13.2 (USA) & 5.9 (CZE) \\
\hline & $\operatorname{Max}$ & 55.7 (NET) & 53.2 (NET) & 62.8 (DEN) & 52.7 (NET) \\
\hline \multirow{3}{*}{$\begin{array}{l}\text { ALMP } \\
\text { expenditure }\end{array}$} & Mean & 0.75 & 0.82 & 0.81 & 0.70 \\
\hline & Min & 0.20 (CHE) & 0.19 (ITA) & 0.17 (CZE) & 0.20 (GRC) \\
\hline & Max & 1.81 (SWE) & 2.52 (SWE) & 2.01 (SWE) & $1.72(\mathrm{DEN})$ \\
\hline
\end{tabular}

Sources: OECD (2004), Employment Outlook, OECD (2008), Labour Force Statistics, online database, Paris: OECD; OECD (2008), Social Expenditure Database, online database, Paris: OECD.

from 1 to 6), unemployment benefit generosity (OECD gross summary replacement rate over four different family types and three different income levels), and active labour market policy (expenditure as a percentage of GDP). Table 1A.2 shows the summary statistics for the relevant time periods, including means, minimum and maximum level.

As mentioned, we used a two-step analysis for the active labour market policy variable to reduce the problem of bi-causality. We first regressed the following model: 


$$
A L M P_{j t}=\beta_{0}+\beta_{1}\left(G D P_{j t}-G D P_{j, t-1}\right)+\mu_{j}+v_{j t}
$$

where $\beta_{1}$ represents the cyclical part of expenditures on active labour market policy in country $j$, whereas $\mu_{j}$ is the country fixed-effect and $v_{j t}$ is the error term. From this regression we calculate the so-called policy part of expenditures on active labour market policy, taking only the country fixed effect and the error term, and we include this variable in our models explained before (also included in the summary statistics in Table 1A.2). Table 1A.3 presents the regression results.

Table 1A.3 Regression results for the analysis of the effect of labour policy instruments

\begin{tabular}{|c|c|c|c|c|c|c|}
\hline & \multicolumn{3}{|c|}{ Employment rate } & \multicolumn{3}{|c|}{ Unemployment rate } \\
\hline & Model 1 & Model 2 & Model 3 & Model 1 & Model 2 & Model 3 \\
\hline EPL & $\begin{array}{c}2.362 \\
(1.604)\end{array}$ & $\begin{array}{c}0.320 \\
(1.584)\end{array}$ & $\begin{array}{c}-0.260 \\
(1.786)\end{array}$ & $\begin{array}{c}-1.180 \\
(1.155)\end{array}$ & $\begin{array}{c}0.389 \\
(1.062)\end{array}$ & $\begin{array}{c}-0.134 \\
(1.192)\end{array}$ \\
\hline UB & $\begin{array}{c}0.121 \\
(0.117)\end{array}$ & $\begin{array}{c}0.095 \\
(0.113)\end{array}$ & $\begin{array}{c}0.125 \\
(0.121)\end{array}$ & $\begin{array}{c}-0.041 \\
(0.085)\end{array}$ & $\begin{array}{c}-0.026 \\
(0.076)\end{array}$ & $\begin{array}{c}0.001 \\
(0.081)\end{array}$ \\
\hline ALMP & $\begin{array}{c}-2.862 \\
(2.137)\end{array}$ & $\begin{array}{c}-2.981 \\
(1.968)\end{array}$ & $\begin{array}{c}-3.134 \\
(1.990)\end{array}$ & $\begin{array}{c}2.972 * \\
(1.538)\end{array}$ & $\begin{array}{l}3.604^{* * *} \\
(1.320)\end{array}$ & $\begin{array}{c}3.466^{* *} \\
(1.328)\end{array}$ \\
\hline EPL*UB & & $\begin{array}{c}-0.228^{* *} \\
(0.094)\end{array}$ & $\begin{array}{c}-0.213^{* *} \\
(0.096)\end{array}$ & & $\begin{array}{l}0.127^{* *} \\
(0.063)\end{array}$ & $\begin{array}{l}0.140^{* *} \\
(0.064)\end{array}$ \\
\hline EPL*ALMP & & $\begin{array}{l}6.638^{* * *} \\
(1.765)\end{array}$ & $\begin{array}{l}6.725^{* * *} \\
(1.779)\end{array}$ & & $\begin{array}{l}-5.068 * * * \\
(1.184)\end{array}$ & $\begin{array}{l}-4.989^{* * * *} \\
(1.187)\end{array}$ \\
\hline UB*ALMP & & $\begin{array}{c}-0.077 \\
(0.139)\end{array}$ & $\begin{array}{c}-0.038 \\
(0.150)\end{array}$ & & $\begin{array}{c}-0.104 \\
(0.094)\end{array}$ & $\begin{array}{c}-0.069 \\
(0.100)\end{array}$ \\
\hline \multirow[t]{3}{*}{ EPL*UB*ALMP } & & & $\begin{array}{c}0.101 \\
(0.140)\end{array}$ & & & $\begin{array}{c}0.091 \\
(0.094)\end{array}$ \\
\hline & \multicolumn{3}{|c|}{ Share of long-term unemployment } & \multicolumn{3}{|c|}{ Inflow into unemployment } \\
\hline & Model 1 & Model 2 & Model 3 & Model 1 & Model 2 & Model 3 \\
\hline EPL & $\begin{array}{c}-1.793 \\
(3.359)\end{array}$ & $\begin{array}{c}3.283 \\
(3.263)\end{array}$ & $\begin{array}{c}0.407 \\
(3.467)\end{array}$ & $\begin{array}{c}-4.166^{* *} \\
(1.709)\end{array}$ & $\begin{array}{c}-3.864 * \\
(1.974)\end{array}$ & $\begin{array}{c}-4.144^{*} \\
(2.189)\end{array}$ \\
\hline UB & $\begin{array}{c}-0.172 \\
(0.252)\end{array}$ & $\begin{array}{c}-0.067 \\
(0.245)\end{array}$ & $\begin{array}{c}0.123 \\
(0.255)\end{array}$ & $\begin{array}{c}0.037 \\
(0.128)\end{array}$ & $\begin{array}{c}0.025 \\
(0.148)\end{array}$ & $\begin{array}{c}0.043 \\
(0.161)\end{array}$ \\
\hline ALMP & $\begin{array}{c}6.776 \\
(4.441)\end{array}$ & $\begin{array}{c}7.647^{*} \\
(3.911)\end{array}$ & $\begin{array}{c}6.914^{*} \\
(3.803)\end{array}$ & $\begin{array}{c}3.173 \\
(2.260)\end{array}$ & $\begin{array}{l}2.608 \\
(2.366)\end{array}$ & $\begin{array}{c}2.536 \\
(2.402)\end{array}$ \\
\hline EPL*UB & & $\begin{array}{l}0.467 * * \\
(0.198)\end{array}$ & $\begin{array}{l}0.528^{* * * *} \\
(0.194)\end{array}$ & & $\begin{array}{c}0.126 \\
(0.120)\end{array}$ & $\begin{array}{c}0.132 \\
(0.123)\end{array}$ \\
\hline EPL*ALMP & & $\begin{array}{c}-15.392 * * * \\
(3.573)\end{array}$ & $\begin{array}{c}-15.133^{* * *} \\
(3.461)\end{array}$ & & $\begin{array}{c}-1.537 \\
(2.162)\end{array}$ & $\begin{array}{l}-1.511 \\
(2.185)\end{array}$ \\
\hline UB*ALMP & & $\begin{array}{c}0.007 \\
(0.292)\end{array}$ & $\begin{array}{c}0.188 \\
(0.296)\end{array}$ & & $\begin{array}{c}0.200 \\
(0.176)\end{array}$ & $\begin{array}{c}0.218 \\
(0.187)\end{array}$ \\
\hline EPL*UB*ALMP & & & $\begin{array}{c}0.544^{*} \\
(0.270)\end{array}$ & & & $\begin{array}{c}0.053 \\
(0.171)\end{array}$ \\
\hline
\end{tabular}


Table 1A.3 (continued)

\begin{tabular}{lccccccc}
\hline & \multicolumn{3}{c}{$\begin{array}{c}\text { Inflow into } \\
\text { employment }\end{array}$} & & \multicolumn{3}{c}{$\begin{array}{c}\text { Expected income loss } \\
\text { unemployment }\end{array}$} \\
\cline { 2 - 5 } \cline { 6 - 8 } & Model 1 & Model 2 & Model 3 & & Model 1 & Model 2 & Model 3 \\
\hline EPL & -0.689 & 0.238 & 0.472 & & -0.783 & 0.551 & 0.307 \\
& $(1.333)$ & $(1.756)$ & $(1.842)$ & & $(0.964)$ & $(0.895)$ & $(1.012)$ \\
UB & $0.126^{*}$ & $0.182^{*}$ & 0.141 & & -0.040 & -0.028 & -0.015 \\
& $(0.067)$ & $(0.095)$ & $(0.124)$ & & $(0.071)$ & $(0.064)$ & $(0.069)$ \\
ALMP & -2.717 & -2.747 & -2.961 & & 2.125 & $2.487^{* *}$ & $2.422^{* *}$ \\
& $(1.586)$ & $(1.688)$ & $(1.766)$ & & $(1.284)$ & $(1.112)$ & $(1.127)$ \\
EPL*UB & & -0.009 & -0.006 & & $0.131^{* *}$ & $0.138^{* *}$ \\
& & $(0.082)$ & $(0.084)$ & & $(0.053)$ & $(0.055)$ \\
EPL*ALMP & & -2.441 & -2.224 & & $-4.382^{* * *}$ & $-4.345^{* * *}$ \\
& & $(1.839)$ & $(1.917)$ & & $(0.998)$ & $(1.008)$ \\
UB*ALMP & & -0.094 & -0.091 & & -0.032 & -0.016 \\
& & $(0.150)$ & $(0.153)$ & & $(0.079)$ & $(0.085)$ \\
EPL*UB*ALMP & & & -0.060 & & & 0.042 \\
& & & $(0.112)$ & & & $(0.079)$ \\
\hline
\end{tabular}

Notes: Standard errors in parentheses, ${ }^{*}=p<0.10,{ }^{* *}=p<0.05,{ }^{* * *}=p<0.01$. Country and time period fixed-effects and constant term included in the analysis but omitted here.

Number of observations ranging from 48 (inflow employment) to 78 (other models).

Sources: Authors' calculations using OECD (2004), Employment Outlook, Paris: OECD (2008), Labour Force Statistics, online database, Paris: OECD; OECD (2008), Social Expenditure Database, online database, Paris: OECD.

\section{NOTE}

1. In formula: $I=u(1-(B / N u) /(W / N(1-u)))=u-(1-u) B / W$, in which $u$ is the unemployment rate, $B$ is total expenditure on unemployment benefits, $W$ is the total wage bill, and $N$ is the labour force. 